\title{
REVISITING HISTORICAL KHOE-SAN SKELETAL REMAINS IN EUROPEAN \\ COLLECTIONS: A SEARCH FOR IDENTITY THROUGH CRANIOMETRIC ANALYSIS
}

\author{
D. Botha ${ }^{a},$, M. Steyn ${ }^{b}$, Y. Scholtz, I. Ribot ${ }^{\mathrm{c}}$
}

${ }^{a}$ Forensic Anthropology Research Centre, Department of Anatomy, University of Pretoria, Private Bag X323, Arcadia, 0007, Pretoria, South Africa.

${ }^{\mathrm{b}}$ School of Anatomical Sciences, University of the Witwatersrand, 7 York Road, Parktown, Johannesburg, South Africa. ${ }^{c}$ Department of Anthropology, University of Montréal, C.P. 6128 Succursale, Centre-ville, Montréal QC H3C 3J7, Canada.

Abbreviated title: Khoe-San craniometric analysis.

*Corresponding author: D. Botha, Tel.: +27 73402 4348, Email: deona.botha@gmail.com

\section{Abstract}

As the identity of a large number of Khoe-San skeletal material in European collections recently came into question during its documentation, a re-evaluation of the remains by employing a non-invasive method such as craniometrics was done to investigate the biological affinity. For this purpose, gene flow and population diversity present within the group, as well as between the study sample $(\mathrm{N}=63)$ and other modern and historic population groups from southern, central and east Africa were explored. Available comparative groups included the historic Khoe-San from Riet River ( $\mathrm{N}=31$ ), the Sotho-Tswana from southern Africa $(\mathrm{N}=61)$, the Basuku from central Africa $(\mathrm{N}=66)$ and the Bahutu $(\mathrm{N}=53)$ and Teita $(\mathrm{N}=24)$ from east Africa. Ten craniometric variables were selected and used to perform population structure analysis based on model bound quantitative genetics and multiple discriminant function analysis (MDA). Quantitative genetic distances revealed that the Khoe-San sample was closest to the Riet River group. Residual variance analysis performed on two-sample subsets of the Khoe-San group (Cape KS and Various KS) showed a higher level of heterogeneity in the Cape KS than seen in the Khoe-San from various other areas in southern Africa. MDA revealed that Khoe-San intra-sample variance is relatively high, with $44 \%$ of the sample (sexes pooled) classified into the Riet River group. The remaining individuals were classified (in decreasing order) into Bahutu (24\%), Basuku (24\%) and Sotho-Tswana (8\%). Although the Khoe-San specimens are closest to the Riet River group, they are clearly not homogenous. Their high level of phenotypic diversity most likely 
originated from a complex population history involving many group interactions driven by social and political marginalization.

\section{Introduction}

Scientific curiosity in the nineteenth century led to the collection of large numbers of Khoe-San remains, many of which were exported to European and American museums (Legassik and Rassool, 2000; Botha and Steyn, 2013; Morris and Scholtz, 2013). These remains were sometimes collected and exported for economic gain, often ruthlessly. As interest was mostly in the skeletal anatomy of Khoe and San peoples, they became the prime "specimens" for acquisition and it can be assumed that the recorded cultural /ethnic /linguistic affinity of some of these individuals were dubious or even totally neglected (Howells, 1973). Morris (1987) points out that researchers who had studied these remains have mostly verified their identity by means of the data recorded in the accession records of the institutions. Such data came from (a) the personal testimonies of the individual describing him- or herself as San or Khoe, (b) testimony from the donor (who often were persons without any training) that the individual was Khoe or San; or (c) circumstantial evidence which may indicate such an affinity. It is possible that many of these assignments to a specific population were incorrect, specifically as far as the distinction between Khoe and San was concerned.

During the last four centuries, the biological variation within the Khoe-San people was most likely altered by changes in their social organization brought about by European colonization of the Cape (Elphick and Shell, 1989). Some of the earliest European accounts of Khoe-San groups distinguished between hunter-gatherers (San) and nomadic herders (Khoekhoe) and declared these two groups mutually exclusive from one another, each of whom also possessed distinct social organization, languages and material culture (Barnard, 1992; Smith et al., 2000). However, with the expansion of the Cape Colony under the Dutch East India Company (VOC), land available to both herders and hunter-gatherers slowly diminished which forced them to retreat northwards (Penn, 2005). Khoe-San populations became surrounded by colonial farmers'settlements and were soon overwhelmed by European economy and political power. Furthermore, southward movement of Bantu-speaking African groups added to the competition for arable land, which led to Khoe and San groups subsequently being assimilated into or partially replaced by other African groups (Newman, 1995). Many Khoe-San individuals became integrated into newly formed social structures (e.g. became employed as farmworkers) in order to survive (Elphick, 1985; Shell, 1994; Smith et al., 2000; Mountain, 2003). Although many Khoe-San populations were integrated into colonial lifestyles and settlements, a few surviving populations retreated to the northern dry regions of southern Africa (Steyn, 1990; Barnard, 1992; Penn, 2013). The original Khoe-San populations 
encountered by the first European colonists during the 1600's are thus no longer in existence, and Morris (1987) described the individuals in Khoe-San collections as "a sample of late historic individuals who represent the dynamic biological reorganization of nineteenth century populations" (p. 20).

Genetic studies have revealed that even though Khoe-San population groups today are small and sometimes isolated, their gene flow into the Cape Coloured group has been substantial (De Wit et al., 2010; Patterson et al., 2010; Quintana-Murci et al., 2010). Mitochondrial DNA (mtDNA) evidence suggests that high frequencies of specific haplogroups (e.g. LOd, L0k) are found in both Khoesan and Coloured populations, but are either absent or present in very low frequencies in other African/comparative groups (Schlebusch et al., 2013). Recent ancient mtDNA analysis even succeeded to trace past genetic diversity, identifying a new lineage (L0d2c1c) on a pre-pastoral skeleton and related this to present-day San-speakers (e.g. Ju) (Morris, 2015). Thus, although genes show substantial diversity within various modern Khoe-San groups suggesting a complex population history (Schlebusch et al., 2012, 2016), morphology does not provide the same results. For example, studies based on craniometric variation of both modern and Later Stone Age (LSA) peoples have failed to provide conclusive evidence that San and Khoekhoe populations are biologically distinct from one another after 2000 B.P. (Rightmire, 1970; Howells, 1973; Morris, 1987, 1992; Stynder et al., 2007; Stynder, 2009). Taking these studies into consideration, the current paper classified all individuals investigated as Khoe-San and made no attempt to distinguish between San and Khoekhoe individuals.

Craniometric studies focus on the degree of variation in skull morphology between different populations and are based on the principle that genes contribute largely to cranial morphology within a population (Froment, 1998; Relethford, 1994, 2001, 2002; Roseman and Weaver, 2007). On a worldwide scale, the human cranial anatomy correlates well not only with genetics and geography, but also with population history and to some extent with climate (Harvati and Weaver, 2006). As craniofacial variation within modern humans is expressed rather early during the ontogenetic trajectory, it supports even more its relatively high heritability (Vidarsdottir et al., 2002). Therefore it is often used as a complementary source of information for genetics, history and archaeology (Ribot, 2004; Stojanowski and Schillaci, 2006; Ossenberg et al., 2006; Franklin et al., 2010; Von CramonTaubadel, 2014). Recent biodistance analyses have also added model bound quantitative genetics, as the latter has the advantage to measure the effects of gene flow (and drift) and therefore to explore how past population structure was shaped (Relethford, 1994; Stojanowski and Buikstra, 2004; Stojanowski and Schillaci, 2006; Ribot et al., 2017). 
In particular, when craniometrics is explored on a small spatio-temporal scale (region, cemetery), subtle gene flow fluctuations can be detected, as was the case in a number of South African studies exploring past morphological variation during the Holocene (e.g., Grine et al., 2007; Stynder et al., 2007, Stynder, 2009; Ribot, 2011). A number of recent bioarchaeological studies have focused on the effects of colonialism throughout the world (Rankin-Hill et al., 2000; Blakey, 2001), and African skeletal collections dating to between A.D. 1600 and the present and located on both sides of the Atlantic Ocean have been (re-)analysed to inform various aspects including health and past variation (Renschler, 2007; Nystrom et al., 2011; Botha and Steyn, 2016; Geller and Stojanowski, 2016; Ribot et al., 2017). Since the $17^{\text {th }}$ century, the composition and distribution of the population of the world has been dramatically re-shaped as a result of Colonialism, war, genocide, epidemics, forced migrations of individuals, and gene flow between local and non-local groups.

However, despite increasing intra-group variation due to admixture during last 2000 years, craniometrics show that Khoe-San (San and Khoekhoe) are considerably different from other sub-Saharan African populations (Howells, 1973; Ribot, 2004; Ribot, 2011; Franklin et al., 2010), as suggested by genetics (Schlebusch et al., 2013) and dental morphology (Irish et al., 2014). However, no research focused so far on the craniometrical variability within the Khoe-San, which could reflect recent historical events involving increased genetic exchange as suggested by genetics above. On this topic, craniometrics can complement genetics in a noninvasive way, although it is less precise than genetics (and dental phenetics).

In the light of these previous historic, genetic and morphologic data, this paper attempts to explore the craniofacial variation of Khoe-San skeletons housed in European collections (dental traits were not observed as dentitions were poorly preserved), and to evaluate the amount of intra-sample variation and gene flow. The effect of gene flow among different Bantu-speaking (Hiernaux, 1976; Franklin et al., 2005; L’Abbé et al., 2006) and Khoe-San (Rightmire, 1970; Ribot, 2004; Franklin et al., 2010) population groups from southern Africa has widely been discussed. However, no attempt was made here to explore differences and/or similarities between Khoe and San, as no archival information was available for this distinction. The Khoe-San sample, which is probably rather heterogeneous (as it was collected across all Southern Africa), was compared craniometrically with other modern and historic populations, not only from South Africa but also from East and Central Africa. In comparative craniometrics, we often assume Khoe-San samples as being rather homogeneous although they are often the results of various large-scale collections. Therefore we argue here that these skeletons from two European museums are probably not homogeneous, as they represent various regions (as suggested by museum archives) and subsequently different gene flow patterns reflecting various population interactions within Southern Africa (as already suggested by modern genetic analyses (Schlebusch et al., 2016). 


\section{Materials}

The Khoe-San crania assessed in this study represent individuals from the late $19^{\text {th }}$ and early $20^{\text {th }}$ century, mostly from the northern regions of South Africa (Table 1, Appendix I). The sample forms part of the large numbers of skeletons that had been exported to Europe more than a century ago and is currently housed at the University of Vienna (Austria) and the National Museum of Natural History (NMNH) in London (England, UK). The total sample analysed here comprises 62 crania of which 53 (21 males and 32 females) are from the Rudolf Pöch Collection (Vienna), and 9 (7 males and 2 females) from the NMNH in London. Information about the area where the skeletons were collected (however not necessarily related to the precise place of origin) was mentioned in the archives for 25 specimens from the Austrian Collection: 24 were documented to be from South Africa (3 from the Western Cape, 16 from the Northern Cape and 5 from the North West region) and 1 from Namibia (Appendix I). All the remaining specimens (23 from the Pöch Collection, and 14 from the $\mathrm{NMNH}$ ) were only labelled as Khoe-San without any additional geographical information. To summarize, 19 out of 62 crania were collected in the Cape region; this fact does not necessarily mean that they originated from this region, but still this cannot be excluded. Therefore, when possible, the Cape Khoe-San was compared to other regions of the collection, in order to explore differences in levels of diversity.

The details regarding health status, age and sex estimation of the individuals in these collections are discussed elsewhere (Botha and Steyn, 2013, 2015, 2016). Only the crania of adults were included in this study. These presumably Khoe-San specimens were compared to various African populations which included four modern Bantu-speaking groups (Sotho-Tswana from South Africa, Basuku, Bahutu and Teita from Central and East Africa) and one archaeological group of Khoe-San (Riet River). These comparative samples were selected based on the availability of published population data that were deemed reliable and for which measurements were taken using the same methodology (Howells, 1989) as for the Khoe-San group. The skeletal samples examined in this study are summarized in Table 1.

The historic Riet River skeletal sample ( $=31)$ is recognized as a Khoe-San group of mixed economy and origin, who lived in the region of the middle Orange River between the $11^{\text {th }}$ and $19^{\text {th }}$ centuries (Rightmire, 1970; Morris, 1992). It corresponded to groups of hunter-gatherers who adopted domestic stock and were semisedentary, which is part of the Iron Age life style. The Riet River sample was selected as a comparative group, as according to morphometric analysis conducted by Morris (1992), it is a rather homogeneous population sample despite some gene flow with the neighbouring agriculturists (especially unidirectionally, between KhoeSan women and Sotho-Tswana men). Furthermore, although morphology cannot distinguish between San and 
Khoi (Morris, 1992), both ethnohistorical and archaeological records support Riet River people having strong cultural affinities with the San (e.g. stock-keeping methods and spatial layout of settlements) (Maggs, 1971; Humphreys, 1972).

Data for the modern Bantu-speaking groups from East $(\mathrm{N}=77)$ and Central $(\mathrm{N}=66)$ Africa were compiled by Ribot $(2003,2004,2011)$ and formed part of a larger study that investigated craniometric variation in subSaharan African groups. South African data on the Sotho-Tswana (N =61) was collected by Morris (1992). Recent studies (Ribot, 2004; Franklin et al., 2010) show that, although all Bantu-speaking groups are morphologically and biologically similar within sub-Saharan Africa, subtle regional differences have been found especially between western and eastern groups. Therefore, this comparative sample was subdivided into at least three geographical groupings (South, East and Central Africans) in order to explore regional differences.

Table 1. List of skeletal populations used in this study.

\begin{tabular}{|l|l|l|l|c|c|}
\hline Group & Origin & Date & Source & $\begin{array}{c}\text { Group } \\
\text { code }\end{array}$ \\
\hline $\begin{array}{l}\text { Khoe-San } \\
\text { 1. Rudolf Poch collection } \\
\text { 2. UK collection }\end{array}$ & Southern Africa & $19^{\text {th }}-20^{\text {th }}$ c. AD & $\begin{array}{c}\text { 1. Botha }(2013,2014) \\
\text { 2. Scholtz (2013) }\end{array}$ & 53 & KS \\
\hline Historic Khoe-San & Riet River, South Africa & $11^{\text {th }}-19$ th c. AD & Morris (1992) & 31 & RR \\
Sotho-Tswana & South Africa & $20^{\text {th }}$ c. AD & & 61 & ST \\
\hline Basuku & DRC, Central Africa & $20^{\text {th }}$ c. AD & & 66 & BAS \\
Bahutu & Rwanda, East Africa & $20^{\text {th }}$ c. AD & Ribot (2003-2011) & 53 & BAH \\
Teita & Kenya, East Africa & $20^{\text {th }}$ c. AD & & 24 & TEI \\
\hline
\end{tabular}

\section{Methods}

Craniometric data were obtained using spreading and sliding callipers. Measurements taken correspond to standards set by Martin and Saller (1959) and Howells (1973, 1989). Ten variables (selected to maximize the sample size) were used in this study and are summarized in Table 2. They include three variables of the cranial vault (GOL, XCB and $\mathrm{BBH})$, three variables of the cranial base (ZYB, BNL and BPL) and four variables of the face (DKB, OBH, NPH and NLB). 
Table 2. Cranial measurements and their descriptions.

\begin{tabular}{|c|c|c|}
\hline $\begin{array}{c}\text { Anatomical } \\
\text { location }\end{array}$ & Description of variable & Code \\
\hline Vault & $\begin{array}{l}\text { Maximum cranial length (glabella - opisthocranion) } \\
\text { Maximum cranial breadth (euryon - euryon) } \\
\text { Cranial height (basion - bregma) }\end{array}$ & $\begin{array}{l}\mathrm{GOL} \\
\mathrm{XCB} \\
\mathrm{BBH}\end{array}$ \\
\hline Face & $\begin{array}{l}\text { Upper facial height (nasion - prosthion) } \\
\text { Inter-orbital breadth (dacryon - dacryon) } \\
\text { Orbital height (superior - inferior margins) } \\
\text { Nasal breadth (alare - alare) }\end{array}$ & $\begin{array}{l}\text { NPH } \\
\text { DKB } \\
\text { OBH } \\
\text { NLB }\end{array}$ \\
\hline Base & $\begin{array}{l}\text { Bizygomatic breath (zygion - zygion) } \\
\text { Total facial length (basion - nasion) } \\
\text { Lower facial length (basion - prosthion) }\end{array}$ & $\begin{array}{l}\text { ZYB } \\
\text { BNL } \\
\text { BPL }\end{array}$ \\
\hline
\end{tabular}

After normality tests, population structure analysis based on model bound quantitative genetics and multiple discriminant function analysis or MDA (model-free) were performed. Analyses were run with pooled sexes and separately for both females and males. Therefore a Z-score standardization of the variables within each sex was calculated and used for the whole sample (Relethford 1994, 2002). Although sexual dimorphism has little influence on the patterns of craniometric variation between different groups on a large scale (Howells, 1989; Pietrusewsky, 2000), it can provide subtle variations within a population in relation to gene flow direction (Stojanowski and Schillaci, 2006; Ribot et al., 2017).

R-matrix analysis was performed using RMET 5.0 (Relethford, 2004), as it explores population structure with several population genetic parameters (Relethford and Blangero, 1990; Relethford, 1994, 2002): i) isolation by distance among groups is assessed with the matrices of inter-group distances; ii) levels of phenotypic diversity between groups are compared with the $\mathrm{F}_{\mathrm{ST}}$ values (ratio of among-group variation to total variation); iii) extralocal gene flow is evaluated with the residual variance analysis (patterns of observed and expected within-group variation. Genetic distances were also calculated for the whole sample and various sample subsets (Khoe-San and one or two comparative groups). Although Fst values are influenced by various factors (e.g. number of groups used, level of heterozygosity of each group), this procedure aimed to compare levels of diversity, and more precisely to explore whether the inclusion or exclusion of some groups, especially the Khoe-San (and its sample sub-sets) tended to contribute to increase or decrease the level of heterogeneity.

Parameter iii) was calculated only with pooled data to maximize sample size and done for only the Khoe-San and the southern Africans (RR, ST). Finally, heritability was set at 0.55 , the value 1 for effective population 
sizes was entered for each group (as it could not be reliably estimated), and FST values were also corrected for sampling bias (Relethford and Blangero, 1990; Relethford, 1994, 2002, 2004).

MDA has the advantage here to explore both inter- and intra-group variation. It weighs and combines several discriminating variables in such a way that the variable intercorrelations are considered and that the ratio of between group-variance to the within-group (total) variance is maximized (Pietrusewsky, 2008). MDA analysis was performed in SPSS 23.0 in a stepwise manner, in order to select the best discriminating variables using the Mahalanobis distance (D2) method and prior probabilities were computed from group sizes (Ribot 2004). The jacknifing method was used to avoid assignation on same individuals causing distortion, and therefore cases were classified without using the misclassified individuals in computing the classification function. In addition to the group classifications obtained with this crossvalidation procedure, the first two posterior probabilities (PP) of belonging to a group were also calculated for each unknown individual (Khoe-San specimens deposited at two European Museums).

\section{Results}

Genetic distances showed that, for pooled sexes (Figure 1a, b) and both sexes separately (Figure 1c, d), the Khoe-San (KS) sample under focus was closest in decreasing order to Riet River (RR) and SothoTswana (ST). A pattern of clinal variation was apparent, reflecting isolation by distance between the Khoe-San and other African groups, with the Basuku (BAS) and the Bahutu (BAH) groups being the furthest away from the KS. However, slight differences were noted. First, when the Khoe-San sample was divided into two groups, those supposedly from the Cape appeared to be more distant from the Riet River group than the other Khoe-San from various other regions and unknown places of collection (Figure 1b). However, the two Khoe-San sub-groups remained at an equal distance from the Sotho-Tswana. Secondly, when the two sexes were analysed separately, the Khoe-San females were slightly closer to the Riet River sample (Figure 1d) than the males (Figure 1c). 
a. pooled sexes

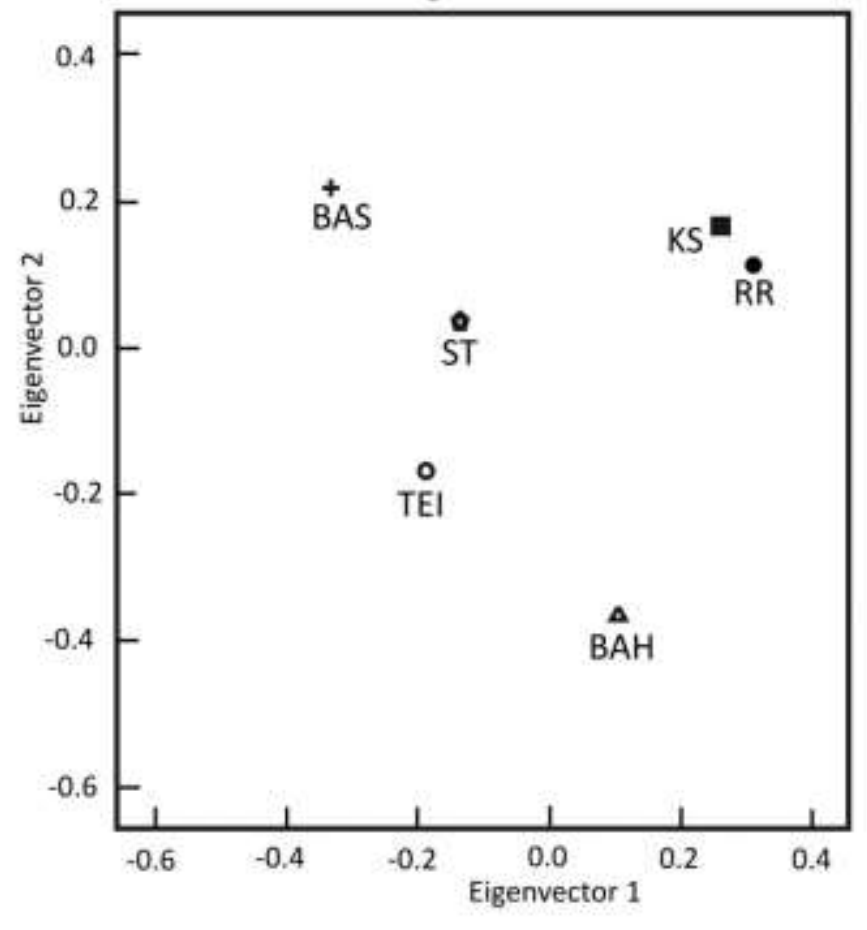

c. males

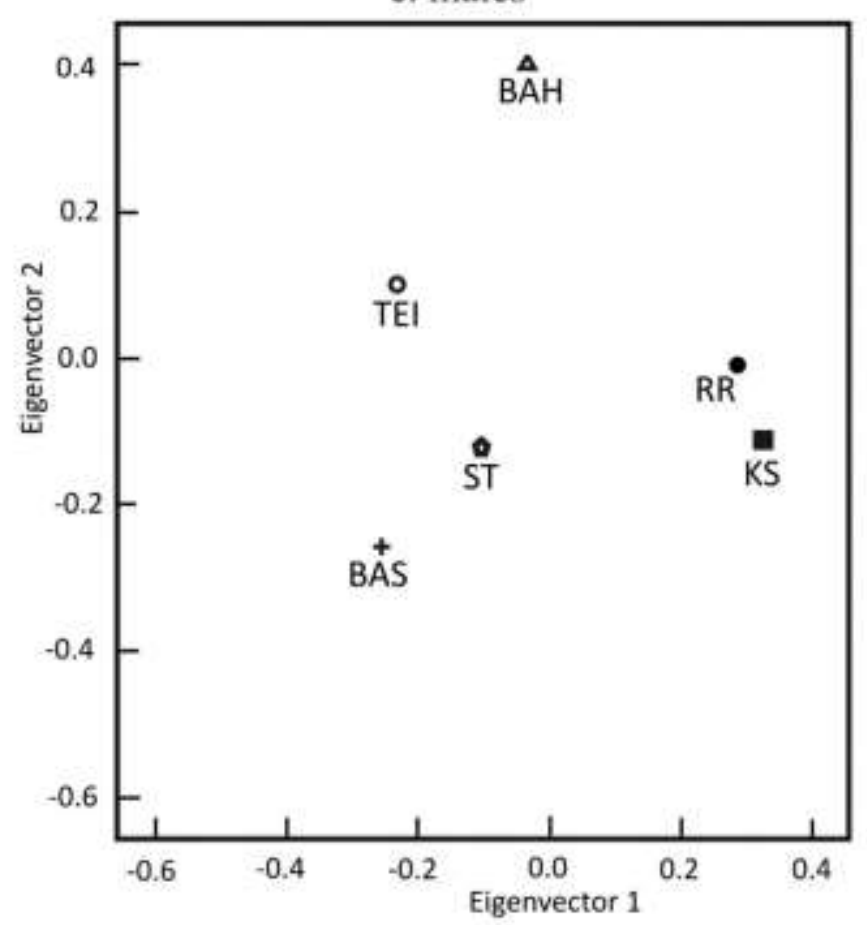

b. same as previous, but Khoe-San in 2 groups

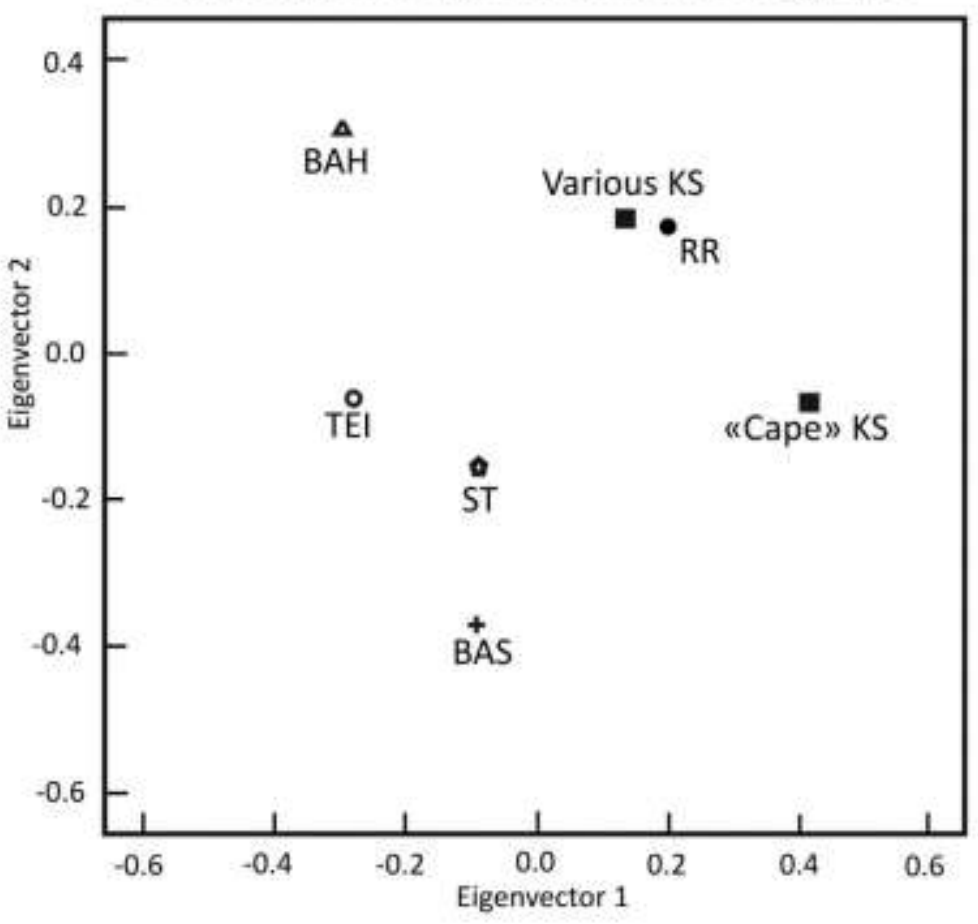

d. females

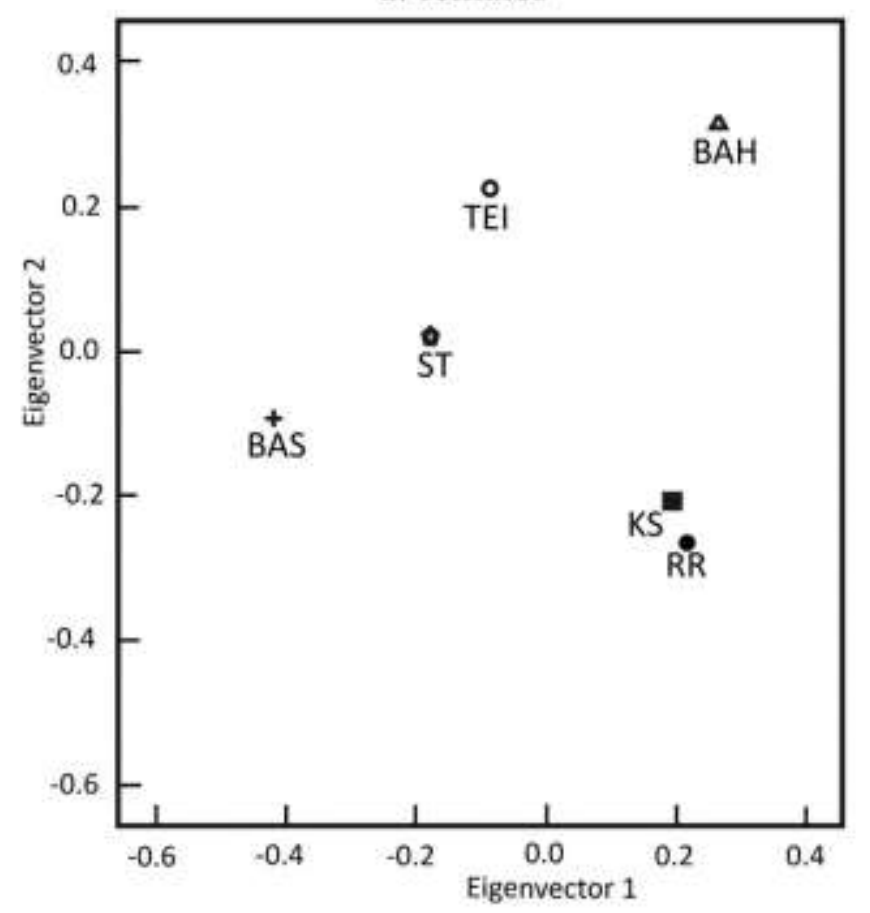

Figure 1. Genetic distance ordinations for the Khoe-San and five comparative groups.

KS=Khoe-San, RR=Riet River (South Africa), ST=Sotho-Tswana (South Africa), BAS=Basuku (DRC), BAH=Bahutu (Rwanda), TEI=Teita (Kenya). 
Levels of phenotypic diversity tended to increase when the analysis combines the Khoe-San sample with a comparative group that was increasingly geographically distant (Table 3). When the whole sample was considered, the range of values (bias-corrected $\mathrm{F}_{\mathrm{ST}}$ : 0.013252-0.13609) appeared comparable to previous African data, especially for their lowest range. Relethford (2002) reported F $_{\text {ST }}$ values between 0.2125 and 0.1136; and Ribot et al. (2017) between 0.2472-0.1278. This may be explained by the fact that the present study was restricted to a reduced number of sub-Saharan African groups. The $\mathrm{F}_{\text {ST }}$ values also appeared slightly higher for the females $\left(\mathrm{F}_{\mathrm{ST}}: 0.13609\right)$ than for the males $\left(\mathrm{F}_{\mathrm{ST}}: 0.13252\right)$.

When analyzing all samples and a two-sample subset (KS and TEI), unbiased $\mathrm{F}_{\mathrm{ST}}$ values were slightly higher once again for females than males. When analyzing one three-sample subset (KS, RS, ST) and five two-sample subsets (KS with each comparative group), they tended to increase, as the Khoe-San's genetic distances with other groups increased. Lowest values were obtained when KS and RR were analysed, especially for the females (pooled sexes: 0.02211; males: 0.02360; females: 0.01962). The highest unbiased $\mathrm{F}_{\mathrm{ST}}$ values were observed between KS and TEI (females: 0.15798; pooled sexes: 0.11223), and between KS and BAS (males: $0.10156)$.

In order to explore levels of diversity within the Khoe-San sample under focus (only with pooled sexes because of small sample size), the $\mathrm{F}_{\mathrm{ST}}$ values calculated for three other two-sample sub-sets (Cape KS, Various KS; Cape KS, RR; Various KS, RR) ranged from 0.02677 to 0.06249 . When the 19 Khoe-San originating supposedly from the Cape (western and northern areas were pooled to maximize sample size) were excluded, the values decreased slightly to the lowest range, supporting a higher level of heterogeneity.

Table 3. $\mathrm{F}_{\mathrm{ST}}$ values with standard errors (se) (See Table 1 and Appendix I for comparative population codes).

\begin{tabular}{|c|c|c|c|c|c|c|c|c|c|}
\hline \multirow[t]{2}{*}{ Sample } & \multicolumn{3}{|c|}{$\mathrm{F}_{\mathrm{ST}}$} & \multicolumn{3}{|c|}{ Unbiased $\mathrm{F}_{\mathrm{ST}}$} & \multicolumn{3}{|c|}{ SE } \\
\hline & Pooled & Males & Females & Pooled & Males & Females & Pooled & Males & Females \\
\hline All & 0.14478 & 0.15718 & 0.15748 & 0.13336 & 0.13252 & 0.13609 & 0.00814 & 0.01216 & 0.01130 \\
\hline KS, RR, ST & 0.08510 & 0.09266 & 0.10502 & 0.07428 & 0.07022 & 0.08414 & 0.00924 & 0.01378 & 0.01405 \\
\hline KS, RR & 0.03421 & 0.04920 & 0.04260 & 0.02211 & 0.02360 & 0.01962 & 0.00864 & 0.01471 & 0.01311 \\
\hline $\mathrm{KS}, \mathrm{ST}$ & 0.09507 & 0.11665 & 0.10970 & 0.08694 & 0.09966 & 0.09401 & 0.01070 & 0.01653 & 0.01558 \\
\hline $\mathrm{KS}, \mathrm{BAS}$ & 0.10246 & 0.11882 & 0.12270 & 0.094100 & 0.10156 & 0.10953 & 0.01051 & 0.01676 & 0.01477 \\
\hline $\mathrm{KS}, \mathrm{BAH}$ & 0.09513 & 0.10478 & 0.10506 & 0.08686 & 0.08659 & 0.08989 & 0.01080 & 0.01654 & 0.01511 \\
\hline KS, TEI & 0.12668 & 0.12684 & 0.18457 & 0.11223 & 0.09518 & 0.15798 & 0.01562 & 0.02312 & 0.02307 \\
\hline \multicolumn{10}{|c|}{ Cape KS, Various KS } \\
\hline & 0.05869 & - & - & 0.03912 & - & - & 0.01384 & - & - \\
\hline Cape KS, RR & 0.06249 & - & - & 0.04053 & - & - & 0.01504 & - & - \\
\hline Various KS, RR & 0.04052 & - & - & 0.02677 & - & - & 0.00992 & - & - \\
\hline
\end{tabular}


Residual variance analysis performed on two-sample subsets (Khoe-San pooled or subdivided in two groups) showed the highest positive residuals for the Cape Khoe-San (0.142), indicating substantial extra-local gene flow (Table 4). For other groups, residuals were close to zero or even negative, with a lowest value for the other Khoe-San sub-sample (-0.117), suggesting less-than-average external biological interaction. Therefore, the Cape Khoe-San is clearly very heterogeneous, as they showed more gene flow than the other sub-sample of various Khoe-San. Although gene-flow patterns seemed to differ between groups, interpretations remained cautious, as it could reflect the manner in which the sample was collected, rather than population history.

Table 4. Two residual variance analyses for Southern Africans with pooled sexes.

$\mathrm{r}_{\mathrm{ii}}$ : regional phenotypic distances to centroid. $\tilde{\mathrm{v}}_{\mathrm{i}}$ : observed mean variance. $\mathrm{E}\left(\tilde{\mathrm{v}}_{\mathrm{i}}\right)$ : expected mean variance. $\tilde{\mathrm{v}}_{\mathrm{i}}-\mathrm{E}\left(\tilde{\mathrm{v}}_{\mathrm{i}}\right)$ : residual variance. See Table 1 and Appendix I for comparative population codes.

\begin{tabular}{|c|c|c|c|c|}
\hline Population & $\mathrm{r}_{\mathrm{ii}}$ & $\tilde{\mathrm{V}}_{\mathrm{i}}$ & $\mathrm{E}_{(\widetilde{\mathrm{v} i})}$ & $\tilde{\mathrm{V}}_{\mathrm{i}}-\mathrm{E}_{(\tilde{\mathrm{v}} \mathrm{i})}$ \\
\hline \multicolumn{5}{|c|}{ When Khoe-San are pooled } \\
\hline $\mathrm{KS}$ & 0.068872 & 0.899 & 0.890 & 0.008 \\
\hline $\mathrm{RR}$ & 0.037370 & 0.951 & 0.921 & 0.031 \\
\hline ST & 0.116605 & 0.805 & 0.845 & -0.039 \\
\hline \multicolumn{5}{|c|}{ When Khoe-San are sub-divided into 2 groups } \\
\hline Cape KS & 0.061611 & 1.068 & 0.926 & 0.142 \\
\hline Various KS & 0.075330 & 0.795 & 0.912 & -0.117 \\
\hline $\mathrm{RR}$ & 0.047555 & 0.951 & 0.940 & 0.012 \\
\hline $\mathrm{ST}$ & 0.146320 & 0.805 & 0.842 & -0.037 \\
\hline
\end{tabular}

The three multiple discriminant analyses yielded four functions for which the eigenvalues are above 0.1 for the first three functions. In general, the most discriminating variables for the first two functions were the cranial height (BBH), nasal breadth (NLB), bizygomatic breadth (ZYB), cranial breadth (XCB), maximum cranial length (GOL) and basion-nasion length (BNL).

The MDA's provided a total group classification rate (after cross-validation) of $63.7 \%$ for the pooled sexes, $63.2 \%$ for males and $61.2 \%$ for females. Pairwise group comparisons between comparative samples indicated that most of the differences were at the highest level of significance, except between the Teita and two groups (BAS, BAH) as well as between Riet River and Sotho-Tswana. This was supported by the classification rates (Tables 5-7): although they were mostly above 50\%, there was some variation. Three groups (BAH, BAS and ST) were differentiated from the others, with a correct classification rate ranging from $81 \%$ to $53 \%$ (the Bahutu corresponding to the highest and the Sotho-Tswana to the lowest). For Riet River, only $50 \%$ to $58 \%$ of the 
sample was correctly classified in its own group, and 22\% (pooled sexes) to $25 \%$ (males and females separately) was misclassified with the Sotho-Tswana group.

Table 5. Classification summary for the comparative groups obtained from the MDA with pooled sexes.

\begin{tabular}{lcrrrr}
\hline & RR & \multicolumn{1}{c}{ ST } & \multicolumn{1}{c}{ BAS } \\
& \multicolumn{1}{c}{$\begin{array}{c}\text { BAH } \\
\%(\mathrm{n})\end{array}$} & \multicolumn{1}{c}{$\begin{array}{c}\text { TEI } \\
\%(\mathrm{n})\end{array}$} & \multicolumn{1}{c}{$\%(\mathrm{n})$} \\
\hline RR & $\mathbf{5 8 . 1 ( 1 8 )}$ & $22.6(7)$ & $6.5(2)$ & $9.7(3)$ & $3.2(1)$ \\
ST & $8.2(5)$ & $\mathbf{5 7 . 4 ( 3 5 )}$ & $18.0(11)$ & $11.5(7)$ & $4.9(3)$ \\
BAS & $4.1(3)$ & $12.3(9)$ & $\mathbf{7 6 . 7 ( 5 6 )}$ & $4.1(3)$ & $2.7(2)$ \\
BAH & $5.1(3)$ & $10.2(6)$ & $8.5(5)$ & $\mathbf{7 4 . 6 ( 4 4 )}$ & $1.7(1)$ \\
TEI & $0.0(0)$ & $8.3(2)$ & $37.5(9)$ & $33.3(8)$ & $\mathbf{2 0 . 8 ( 5 )}$ \\
\hline
\end{tabular}

See Table 2 for comparative group codes.

Table 6. Classification summary for the comparative groups obtained from the MDA with only the males.

\begin{tabular}{lcrrrr}
\hline & \multicolumn{1}{c}{ RR } & \multicolumn{1}{c}{ ST } & \multicolumn{1}{c}{ BAS } & \multicolumn{1}{c}{ BAH } & \multicolumn{1}{c}{ TEI } \\
& \multicolumn{1}{c}{$\%(\mathrm{n})$} & \multicolumn{1}{c}{$\%(\mathrm{n})$} & \multicolumn{1}{c}{$\%(\mathrm{n})$} & \multicolumn{1}{c}{$\%(\mathrm{n})$} & \multicolumn{1}{c}{$\%(\mathrm{n})$} \\
\hline RR & $\mathbf{5 0 . 0}(\mathbf{8})$ & $25.0(4)$ & $6.3(1)$ & $18.8(3)$ & $0.0(0)$ \\
ST & $6.7(2)$ & $\mathbf{5 3 . 3 ( 1 6 )}$ & $30.0(9)$ & $10.0(3)$ & $0.0(0)$ \\
BAS & $2.3(1)$ & $16.3(7)$ & $\mathbf{7 4 . 4 ( 3 2 )}$ & $2.3(1)$ & $4.7(2)$ \\
BAH & $3.1(1)$ & $9.4(3)$ & $3.1(1)$ & $\mathbf{8 1 . 3 ( 2 6 )}$ & $3.1(1)$ \\
TEI & $0.0(0)$ & $23.1(3)$ & $38.5(5)$ & $38.5(5)$ & $\mathbf{0 . 0}(\mathbf{0})$ \\
\hline
\end{tabular}

See Table 2 for comparative group codes.

Table 7. Classification summary for the comparative groups obtained from the MDA with only the females.

\begin{tabular}{|c|c|c|c|c|c|}
\hline & $\mathrm{RR}$ & ST & BAS & BAH & TEI \\
\hline & $\%(\mathrm{n})$ & $\%(\mathrm{n})$ & $\%(\mathrm{n})$ & $\%(\mathrm{n})$ & $\%(\mathrm{n})$ \\
\hline $\mathrm{RR}$ & $50.0(8)$ & $25.0(4)$ & $6.3(1)$ & $18.8(3)$ & $0.0(0)$ \\
\hline ST & $6.7(2)$ & $53.3(16)$ & $30.0(9)$ & $10.0(3)$ & $0.0(0)$ \\
\hline BAS & $2.3(1)$ & $16.3(7)$ & $74.4(32)$ & $2.3(1)$ & $4.7(2)$ \\
\hline BAH & $3.1(1)$ & $9.4(3)$ & $3.1(1)$ & $81.3(26)$ & $3.1(1)$ \\
\hline TEI & $0.0(0)$ & $23.1(3)$ & $38.5(5)$ & $38.5(5)$ & $0.0(0)$ \\
\hline
\end{tabular}

See Table 2 for comparative group codes.

The Khoe-San intra-sample variation was very high, as shown with the probabilistic affinities (Appendix II). According to first PPs, the Khoe-San individuals were classified into various groups (Appendix II). Table 8 summarized the detailed results of Appendix II for the Khoe-San sample as a whole, by region and by sex (either pooled or separately). The number of individuals with a first $\mathrm{PP} \geq 50 \%$ of belonging to a comparative 
group were presented in a decreasing order. When sexes were pooled, $44 \%$ of the sample (27 out of 62) was classified with the Riet River group, and when only males were considered the percentage was even higher $(50 \%)$, but slightly lower with only the females $(38 \%)$. The remainder of the sample was classified in a variable manner with 3 groups, in a broadly decreasing order: the Bahutu (pooled sexes: 24\%; males: 18\%; females: 26\%), the Basuku (pooled sexes: 24\%; males: 21\%; females: 32\%) and the Sotho-Tswana (pooled sexes: 8\%; males: $11 \%$; females: $3 \%$ ). If we look at the distribution of the classifications by region (where skeletons were collected) (Table 8), an important observation can be made: individuals from the Northern Cape region and from unknown regions tend to classify with the Riet River group (ranges: $55 \%$ to 57\% and 38\% to 50\% respectively).

Table 8. Summary of the classification of the Khoe-San sample based on the data in Appendix II.

\begin{tabular}{|c|c|c|c|c|c|c|c|c|c|}
\hline \multirow[t]{2}{*}{ Region } & \multicolumn{3}{|c|}{ Pooled sexes } & \multicolumn{3}{|c|}{ Only males } & \multicolumn{3}{|c|}{ Only females } \\
\hline & $\overline{\mathbf{N}}$ & $\begin{array}{l}\mathrm{N} \text { with } \\
1^{\text {st }} \mathrm{PP} \\
\geq 50 \%\end{array}$ & $\begin{array}{c}\text { Closest } \\
\text { groups* }(\mathrm{N})\end{array}$ & $\mathbf{N}$ & $\begin{array}{l}\mathrm{N} \text { with } \\
1^{\text {st }} \mathrm{PP} \\
\geq 50 \%\end{array}$ & $\begin{array}{c}\text { Closest } \\
\text { groups* }(\mathrm{N})\end{array}$ & $\mathbf{N}$ & $\begin{array}{l}\mathrm{N} \text { with } \\
1^{\text {st }} \mathrm{PP} \\
\geq 50 \%\end{array}$ & $\begin{array}{c}\text { Closest } \\
\text { groups* }(\mathrm{N})\end{array}$ \\
\hline Northern Cape & 16 & 9 & $\begin{array}{l}\text { RR (9), BAS (6), } \\
\text { ST (1) }\end{array}$ & 9 & 5 & RR (5), BAS (4) & 7 & 5 & $\begin{array}{l}\text { RR (4), BAS } \\
\text { (3) }\end{array}$ \\
\hline Western Cape & 3 & 1 & $\begin{array}{l}\mathrm{ST}(1), \mathrm{RR}(1), \\
\mathrm{BAH}(1)\end{array}$ & 2 & 2 & ST (2) & 1 & 1 & BAS (1) \\
\hline North West region & 5 & 5 & BAS (3), RR (2) & 1 & - & $\mathrm{RR}(1)$ & 4 & 3 & BAS (4) \\
\hline Namibia & 1 & 0 & BAH (1) & & - & - & 1 & 1 & $\mathrm{RR}(1)$ \\
\hline$?$ & 37 & 24 & $\begin{array}{l}\text { RR (15), BAH } \\
(13), \text { BAS (6), } \\
\text { ST (3) }\end{array}$ & 16 & 11 & $\begin{array}{l}\text { RR (8), BAH (5), } \\
\text { BAS (2), ST (1) }\end{array}$ & 21 & 15 & $\begin{array}{l}\text { BAH (9), RR } \\
(8), \text { BAS (3), } \\
\text { ST (1) }\end{array}$ \\
\hline Total & 62 & 39 & $\begin{array}{l}\text { RR (27), BAH } \\
(15), \text { BAS (15), } \\
\text { ST (5), TEI (0) }\end{array}$ & 28 & 18 & $\begin{array}{l}\text { RR (14), BAS (6), } \\
\text { BAH (5), ST (3), } \\
\text { TEI (0) }\end{array}$ & 34 & 25 & $\begin{array}{l}\text { RR (13), BAS } \\
\text { (11), BAH } \\
\text { (9), ST (1), } \\
\text { TEI (0) }\end{array}$ \\
\hline
\end{tabular}

*In decreasing order.

\section{Discussion}

In this study, craniometric data were used to estimate the genetic relationship between supposedly modern Khoe-San individuals collected during the colonial period and neighbouring African groups of known ethnic origin, but also the amount of intra-sample variation within the unknown sample under focus. They provided the opportunity to explore biological affinities and possible gene flow between various Southern African groups in 
particular, both Khoe-San and non Khoe-San (e.g. Bantu speaking groups), who share a complex history of interactions that probably started since at least the Early Iron Age (EIA) period (e.g. Maggs, 1971; Morris, 1992; Ribot et al., 2010).

Re-visiting historical African collections in European museums, is part of an important step for African researchers, who need to examine their continental biohistory. Within this perspective, these Khoe-San human remains, who most probably date back to the colonial period, correspond to a key period of social transformations and upheaval (Elphick, 1985; Shell, 1994; Steyn, 1990; Barnard, 1992; Penn 2013).

The initial assumption was, despite the lack of precise information on the origin of the Khoe-San under focus that it would be rather heterogeneous, having been collected within Southern Africa. Although the initial underlying question was to confirm the biological affinity of the Khoe-San and the identity of the latter, it expanded into a deeper analysis of intra-sample variation, which is often neglected phenotypically for these groups.

The discussion below is divided therefore into two sections: the first section focuses on the predominant affinities of the Khoe-San group using genetic distances and $\mathrm{F}_{\mathrm{ST}}$ values (population structure analysis); while the second focuses on the intra-sample diversity revealed by both the residual variance analysis (population structure analysis) and the posterior probabilities (multiple discriminant analysis).

\section{Predominant affinities of the Khoe-San sample under focus}

Not surprisingly, both genetic distance ordinations (Fig.1) and $\mathrm{F}_{\mathrm{ST}}$ values (Table 3) showed that the Khoe-San sample under study (KS) exhibited an isolation by distance throughout sub-Saharan Africa in all cases (pooled or unpooled sexes). As the tested sample was geographically closest to another San group from the Riet River, its biological affiliation to the latter supports an isolation by distance model. As geographical distance increased between groups, the genetic distance increased and clinal variation was visible between sub-Saharan Bantuspeaking groups. As predicted, the non Khoe-San group, which was phenotypically closest to the Khoe-San group under focus, appeared to be the geographically closest to the Sotho-Tswana. These facts together suggest that gene flow possibly occurred between mainly our Khoe-San sample (KS) and the San group (RR), as well as, to some extent the Southern African Bantu group (ST).

Nonetheless, the Khoe-San sample under focus (KS) did not appear to be homogeneous. Although the level of heterogeneity ( $\mathrm{F}_{\mathrm{ST}}$ values) tended to decrease when only the Khoe-San were considered, it was always well 
above 0 (Table 3). In particular, when the Khoe-San sample under focus (KS) was subdivided in two different sub-samples according to possible origin, the one from the Cape ("Cape" KS) appeared to be rather distant from the remaining (Various KS) and the comparative San (RR) and at a nearly equal distant from the Sotho-Tswana (Fig.1b). The F $\mathrm{F}_{\mathrm{ST}}$ values also showed that the inclusion of the "Cape" Khoe-San increased the level of heterogeneity (Table 3). This fact could reflect possibly some isolation by distance: the "Cape" Khoe-San might have been differentiated from the other Khoe-San and different gene flow patterns might have impacted their genetic pool as suggested by modern genetics (Schlebusch et al., 2013, 2016). The residual variance analysis supported this hypothesis even more, as it showed substantial extra-local gene flow within the "Cape" KhoeSan (Table 4).

It is here important to remember that the Cape region in South Africa reflects complex population dynamics and socio-cultural factors up to the colonial times (Shell, 1994; Mountain, 2003): interactions occurred not only between Khoekhoe and San, but also between the latter, various Bantu-speakers and non-Africans. As historical sources suggest, geneticists (e.g. Quintana-Murci et al., 2010) have revealed strong maternal Khoisan contribution to the South African Coloured population, our phenotypical results might not be so surprising. The outlying position of the "Cape" Khoe-San within the Khoe-San variation (Fig. 1b) might suggest that various factors, not only isolation, but also gene flow, increased the Cape KS's differentiation from other regions. However, it is important to remember that the present study included only one comparative South African Bantu group (Sotho-Tswana) but did not have many other groups such as the southern Nguni-speakers, who admixed a lot with the Khoe-San (Shell, 1994). Because of this lack, the outlying position of the Cape KhoeSan within the variation might have been slightly exaggerated.

Nevertheless, the phenotypic data remains difficult to interpret, as it is not entirely sure that the supposedly "Cape" Khoe-San collection originated from this region. If they were broadly collected within the Cape Province, they should show predominant affinities as discussed above and provide some information about intra-regional variation. That is why the intra-sample analysis was necessary, as it explored further individual variation and not only group affinity.

\section{High levels of diversity within the Khoe-San}

Although the population structure analysis supported the Khoe-San identity of our sample under focus (KS) with predominant affinities with the San (RR) - it also suggested high levels of diversity. This was further tested with multiple discriminant analyses that explored the biological affinities of each specimen in probabilistic 
terms. A clinal variation was revealed by the classifications results within the whole sample, similarly suggesting isolation by distance as the comparative San sample (RR) was often misclassified with geographically neighbouring Bantu-speaking groups (Sotho-Tswana). This fact supported biocultural interactions between San and Bantu groups already documented by previous research in the Orange River Valley (Maggs, 1971; Humphreys, 1972; Morris, 1992). Therefore the Riet River sample was probably not ideal for the present study, as levels of admixture could have increased the comparative intra-group variability to some extent.

Nevertheless, the heterogeneity of the Khoe-San sample under focus was also well confirmed by the posterior probabilities (Table 8, Appendix II). Only half to a third of the sample was classified with the comparative San group: males (50\%) were often closer to the latter than females $(38 \%)$, who showed greater similarity with other groups. This fact in particular might reflect traces of asymmetrical gene flow, as such patterns have been reported earlier by geneticists (e.g. De Wit et al., 2010; Patterson et al., 2010; Quintana-Murci et al., 2010) and ethnohistorical and archaeological accounts (Maggs, 1971; Humphreys, 1972; Morris, 1992). As Khoe-San women tended to move more often to marry agriculturists, it is to be expected to find greater diversity within the female group than the male one, who tended not to mix. However, because of small sample size and as sex estimation was based on the crania, these interpretations have to be considered with caution. In addition, although biological affinities based on phenotypic data are generally broadly correlated with genetics, they might not be as precise, as the latter can distinguish between paternal and maternal contributions (Hubbard et al., 2015; Irish, 2016).

In contrast to population structure analysis, the Bantu-speaking groups which appeared closest to the Khoe-San specimens under study, were not closest geographically. Surprisingly, East and Central African cranial morphology (e.g. Bahutu, Basuku) was more similar to the Khoe-San (KS) than the Southern African sample (e.g. Sotho-Tswana). However, this might be explained by the fact that model-free multivariate statistics (MDA) weighed and combined the most discriminating variables (six out of ten, all related to face and vault), to both maximize group differentiation and provide classification results. In contrast, model-bound statistics provided biodistances based on the overall diversity (e.g. average distance of each group from a regional centroid) and calculated on the initial set of ten variables weighted equally (Relethford, 2004; Stojanowski, 2013). 


\section{Conclusion}

Finally, this craniometrical study shows that it is possible to revisit historical Khoe-San collections, although the latter had some collection and classification issues, and to propose to some extent interpretations about population history. It showed that, although the Khoe-San specimens from two European museums are closest to some historic San groups, they are not homogeneous at all. Both model-bound and model-free analyses showed high level of phenotypical diversity that can be explained by not only the large-scale collection methods but also complex population history. Group interactions increased in Southern Africa especially following the immigration of Bantu-speakers and later non-African groups, as is suggested by genetics (e.g. De Wit et al., 2010) and dental phenetics (Irish et al., 2014). Therefore the affinities of historic San have to be interpreted differently than those for earlier periods, and as a consequence not lumped together as a homogeneous group based on lack of information.

These analyses also underlined the utility of biodistance analysis for museum collections that have poorly documented specimens. Phenotypical variation within and between groups showed that different gene flow patterns might have shaped the diversity of the Khoe-San in the $19^{\text {th }}$ and early $20^{\text {th }}$ centuries. It revealed a biological diversity that might be already extinct in some cases as suggested by geneticists (e.g. Schlebusch, 2013, 2016), and why it is necessary to study past populations at various periods in time. Further studies combining both (cranial and dental) morphology and paleogenetics are needed to explore in detail the recent transformation of past Southern African diversity. A more exhaustive sampling of comparative groups especially for South Africa (e.g. Nguni) also needs to be done, in order to explore further the levels of admixture between the Khoe-San and the Bantu communities.

\section{Acknowledgements}

The authors would like to thank Rob Kruszynski (National Museum of Natural History, London) and Gerhard Weber (University of Vienna) for allowing us to access the skeletal materials. We acknowledge the financial support provided by SANPAD. The research of M Steyn is supported by the National Research Foundation of South Africa. The research of I Ribot is supported by the University of Montreal, Quebec, Canada (Sabbatical funds). Thanks are due to John Relethford for providing access to the RMET 5.0 program and advice on the Rmatrix analyses. All statistical errors remain the responsibility of the authors. A special thanks to the reviewers Dr Amelia Hubbard and Dr Kerryn Warren, who significantly improved the paper. 


\section{References}

Barnard, A., 1992. Hunter and Herders of Southern Africa: A Comparative Ethnography of the Khoisan Peoples. Cambridge University Press, Cambridge.

Beals, K.L., 1972. Head form and climatic stress. Am. J. Phys. Anthropol. 37, 85-92.

Beals, K.L., Smith, C.L., Dodd, S.M., 1984. Brain size, cranial morphology, climate, and time machines. Curr. Anthropol. 25, 301-330.

Blakey, M.L., 2001. Bioarchaeology of the African diaspora in the Americas: Its origin and scope. Ann. Rev. Anthropol. 30, 387-422.

Botha, D., Steyn, M., 2013. Khoe-San skeletal collections in Vienna and Paris: Origin, history and context. S. Afr. Archaeol. Soc. Goodwin Series 11, 7-12.

Botha, D., Steyn, M., 2015. Dental health of the late $19^{\text {th }}$ and early $20^{\text {th }}$ century Khoesan. HOMO 66, $187-202$.

Botha, D., Steyn, M., 2016. A palaeopathological assessment of the late $19^{\text {th }}$ and early $20^{\text {th }}$ century Khoesan. Int. J. Osteoarchaeol. 26, 266-280.

Cavalli-Sforza, L., Menozzi, P., Piazza, A., 1994. The history and geography of human genes. Princeton University Press, Princeton.

Cruciani, F., Santolamazza, P., Peidong, S., Macaulay, V., Moral, P., Olckers, A., Mondiano, D., Holmes, S., Destro-Bisol, G., Coia, V., Wallace, D.C., Oefner, P.J., Torroni, A., Cavalli-Sforza, L.L., Scozzari, R., Underhill, P.A., 2002. A back migration from Asia to sub-Saharan Africa is supported by high-resolution analysis of human Y-chromosome haplotypes. Am. J. Hum. Genet. 70, 1197-1214.

De Wit, E., Delport, W., Rugamika, C.E., Meintjies, A., Möller, M., Van Helden, P.D., Seoighe, C., Hoal, E.G., 2010. Genome-wide analysis of the structure of the South African coloured population in the Western Cape. Hum. Genet. 128(2), 145-153.

Elphick, R., 1985. Khoikhoi and the founding of white South Africa. Raven Press, Johannesburg.

Elphick, R., Shell, R., 1989. Intergroup relations: Khoikhoi, settlers, slaves and free blacks, 1652-1795. In: Elphick, R., Giliomee, H.B., Middleton, C.T. (Eds.), The Shaping of South African Society, 1652-1840. Wesleyan University Press, pp., 184-239. 
Franklin, D., Freedman, L., Milne, N., 2005. Three-dimensional technology for linear morphological studies: a re-examination of cranial variation in four southern African indigenous populations. HOMO 56, 17-34.

Franklin, D., Cardini, A., Oxnard, C.E., 2010. A geometric morphometric approach to the quantification of population variation in sub-Saharan African crania. Am. J. Hum. Biol. 22, 23-35.

Froment, A., 1998. Le peuplement de l'Afrique Centrale: Contribution de al paléoanthropologie. In: Delneuf, M., Essomba, J.M., Froment, A. (Eds). Paléoanthropologie en Afrique Central: Un Bilan de l'Archéologie au Cameroun. L'Harmattan, Paris, pp. 13-90.

Geller, P.L., Stojanowski, M.C., 2016. The vanishing Black Indian: Revisiting craniometry and historic collections. Am. J. Phys. Anthropol. DOI: 10.1002/ajpa.23115.

Grine, F.E., Bailey, R.M., Harvati, K., Nathan, R.P., Morris, A.G., Henderson, G.M., Ribot, I., Pike, A.W.G., 2007. Late Pleistocene human skull from Hofmeyr, South Africa, and modern human origins. Science 513(5809), 226-229.

Harvati, K., Weaver, T.D., 2006. Human cranial anatomy and the differtial preservation of population history and climate signatures. Anat. Rec. 288A(12), 1225-1233.

Hiernaux, J., 1976. Physical anthropology of the living populations of sub-Saharan Africa. Ann. Rev. Anthropol. 5, 149-168.

Howells, W.W., 1973. Cranial variation in man. A study by multivariate analysis of patterns of difference among recent human populations. Papers of the Peabody Museum of Archaeology and Ethnology 67, 1259.

Howells, W.W., 1989. Skull shapes and the map: craniometrics analysis in the dispersion of modern homo. Papers of the Peabody Museum of Archaeology and Ethnology 79.

Hubbard, A.R., Guatelli-Steinberg, D., Irish, J.D., 2015. Do nuclear DNA and dental nonmetric data produce similar reconstructions of regional population history? An example from modern coastal Kenya. Am. J. Phys. Anthropol. 157, 295-304.

Humphreys, A.J.B., 1972. The type R settlements in the context of the later prehistory and early history of the Riet River Valley. Unpublished MA Thesis, University of Cape Town. 
Irish, J.D., 2016. Who were they Really? Model-Free and model-bound dental nonmetric analyses to affirm documented population affiliations of seven South African "Bantu” samples. Am. J. Phys. Anthropol. 159, 655-670.

Irish, J.D., Black, W., Sealy, J., Ackermann, R.R., 2014. Questions of Khoesan continuity: Dental affinities among the indigenous Holocene peoples of South Africa. Am. J. Phys. Anthropol. 155, 33-44.

L'Abbé, E.N. 2005. A craniometrics study of the $20^{\text {th }}$ century Venda. S. Afr. Archaeol. Bull. 61, 19-25.

Legassick, M., Rassool, C., 2000. Skeletons in the Cupboard: South African Museums and the Trade in Human Remains, 1907-1917. McGregor Museum, Kimberley.

MacEachern, S., 2000. Genes, tribes and African history. Curr. Anthropol. 41, 357-384.

Maggs, T., 1971. Pastoral settlements on the Riet River. S. Afr. Archaeol. Bull. 26, 37-63.

Martin, R., Saller, K., 1959. Lehrbuch der Anthropologie. Gustav Fischer Verlag, Stuttgart.

Morris, A.G., 1987. The reflection of the collector: San and Khoi skeletons in museum collections. S. Afr. Archaeol. Bull. 42, 12-22.

Morris, A.G., 1992. The skeletons of contact: a study of protohistoric burials from the Lower Orange River Valley, South Africa. Witwatersrand University Press, Johannesburg.

Morris, A.G., Scholtz, Y., 2013. An historical note and preliminary assessment of the human skeletal remains from southern Africa stored in the United Kingdom. S. Afr. Archaeol. Soc. Goodwin Series 11, 21-26.

Morris, A.G., 2014. Ancient DNA comes of age. S. Afr. J. Sci. 111(5/6): 2 pages.

Mountain, A., 2003. The First People of the Cape. David Philip, Claremont.

Newman, J.L., 1995. The Peopling of Africa: A Geographic Interpretation. Yale University Press, London.

Nystrom, N.C., Amato, L.A., Jankowitz, L.A., 2011. Stronium isotope reconstruction of the composition of an urban black population from the $19^{\text {th }}$ century United States. J. Archaeol. Sci. 38(12), 3505-3517.

Ossenberg, N.S., Dodo, Y., Maeda, T., Kawakudo, Y., 2006. Ethnogenesis and craniofacial change in Japan from the perspective of nonmetric traits. Anthropol. Sci. 114(2), 99-115.

Patterson, N., Petersen, D.C., Van der Ross, R.E., Sudoyo, H., Glashoff, R.H., Marzuki, S., Reich, D., Hayes, V.M., 2010. Genetic structure of a unique admixed population: implications for medical research. Hum. Mol. Genet. 19(3), 411-419. 
Penn, N., 2005. The Forgotten Frontier: Colonist and Khoisan on the Cape's Northern Frontier in the $18^{\text {th }}$ Century. Double Storey Books, Cape Town.

Penn, N., 2013. The British and the "Bushmen": The massacre of the Cape San, 1795-1828. J. Gen. Res. 15(2), 183-200.

Pietrusewsky, M., 2000. Metric analysis of skeletal remains: methods and applications. In: Katzenberg, M., Saunders, S.M. (Eds.), Biological Anthropology of the Human Skeleton. Wiley-Liss, New York, pp. 375415.

Prugnolle, F., Manica. A., Balloux, F., 2005. Geography predicts neutral genetic diversity of human populations. Curr. Biol. 15, R159-R160.

Quintana-Murci, L., Harmant, C., Quach, H., Balanovsky, O., Zaporozhchenko, V., Bormans, C., Van Helden, P.D., Hoal, E.G., Behar, D.M., 2010. Strong maternal Khoisan contribution to the South African coloured population: A case of gender-biased admixture. Am. J. Hum. Genet. 86(4), 611-620.

Rankin-Hill, L.M., Blakey, M.L., Carrington, S.H.H., Howson, J.E., 2000. Political economy of fertility and population growth among enslaved Africans in colonial New York. Am. J. Phys. Anthropol. 111(S30), 259.

Relethford, J.H., 1994. Craniometric variation among modern human populations. Am. J. Phys. Anthropol. 95(1), 53-62.

Relethford, J.H., 1997. Hemispheric differences in human skin color. Am. J. Phys. Anthropol. 104, 449-457.

Relethford, J.H., 2001. Global analysis of regional differences in craniometric diversity and population substructure. Hum. Biol. 73(5), 629-636.

Relethford, J.H., 2002. Apportionment of global human genetic diversity based on craniometrics and skin colour. Am. J. Phys. Anthropol. 118(4), 393-398.

Relethford, J.H., Blangero, J., 1990. Detection of differential gene flow from patterns of quantitative variation. Hum. Biol. 62, 5-25.

Renschler, E.S., 2007. An Osteobiography of an African Diasporic Skeletal Sample: Intergrating Skeletal and Historical Information. Unpublished PhD Thesis: University of Pennsylvania, Philadelphia.

Ribot, I., 2003. Craniometrical analysis of Central and East Africans in relation to history: a case study based on unique collections of known ethnic affiliation. Anthropologica et Praehistorica 114, 1-26. 
Ribot, I., 2004. Differentiation of modern sub-Saharan African populations: craniometric interpretation in relation to geography and history. Bulletins et Mémoires de la Société d'Anthropologie de Paris 16, 143165.

Ribot, I., Morris, A.G., Sealy, J., Maggs, T., 2010. Population history and economic change in the last 2000 years in KwaZulu-Natal, RSA. South African Humanities, Natal Museum.

Ribot, I., 2011. A study through skull morphology on the diversity of Holocene African populations in a historical perspective. BAR International Series 2215.

Ribot, I., Morris, A.G., Renschler, E., 2017. Craniometry as a tool to assess population dynamics - two case studies (South African and Cuba). In: Murphy, M., Haagen, K. (Eds.), Colonized Bodies, Worlds Transformed: Toward a Global Bioarchaeology of Contact and Colonialism. University Press of Florida, Florida, pp. 339-370.

Rightmire, G.P., 1970. Bushmen, Hottentot and South African Negro crania studied by distance and discrimination. Am. J. Phys. Anthropol. 33, 169-196.

Roseman, C.C., Weaver, T.D., 2007. Molecules versus morphology? Not for the human cranium. Bioessays. 29(12), 1185-1188.

Schlebusch, C.M., Skoglund, P., Sjödin, P., Gattepaille, L.M., Hernandez, D., Jay, F., Li, S., De Jongh, M., Singleton, A., Blum, M.G.B., Soodyall, H., Jakobsson, M., 2012. Genomic variation in seven Khoe-San groups reveal adaptation and complex African history. Science 338, 374-379.

Schlebusch, C.M., Lombard, M., Soodyall, H., 2013. MtDNA control region variation affirms diversity and deep sub-structure in populations from southern Africa. BMC Evolutionary Biology 13, 56.

Schlebusch, C.M., Prins, F., Lombard, M., Jakobsson, M. \& Soodyall, H. 2016. The disappearing San of southeastern Africa and their genetic affinities. Hum. Genet. 135, 1365-1373.

Shell, R., 1994. Children of Bondage. Witwatersrand University Press, Johannesburg, South Africa.

Smith, A., Malherbe, C., Guenther, M., Berens, P., 2000. The Bushmen of Southern Africa: A Foraging Society in Transition. David Philip, Cape Town.

Steyn, H.P., 1990. Vanished lifestyles: the early Cape Khoi and San. Unibook Publishers, Pretoria. 
Steyn, M., Morris, A.G., Maat, G.J.R., Mosothwane, M.N., (Editors). 2013. Skeletal Identity of Past Southern African Populations: Lessons from Outside South Africa. South African Archaeological Bulletin Goodwin Series Volume 11.

Stojanowski, C.M., 2013. Mission cemeteries, mission peoples: historical and evolutionary dimensions of intracemetery bioarchaeology in Spanish Florida. The University Press of Florida., Gainesville, Florida.

Stojanowski, C.M., Buikstra, J.E., 2004. Biodistance analysis, a biocultural enterprise: A rejoinder to Armelagos and Van Gerven (2003). Am. Anthropol. 106(2), 430-431.

Stojanowski, C.M., Schillaci, M.A., 2006. Phenotypic approaches for understanding patterns of intracemetery biological variation. Yearb. Phys. Anthropol. 49, 49-88.

Stynder, D.D., 2009. Craniometric evidence for South African Later Stone Age herders and hunter-gatherers being a single biological population. J. Archaeol. Sci. 36, 798-806.

Stynder, D.D., Ackermann, R.R., Sealy, J.C., 2007. Craniofacial variation and population continuity during the South African Holocene. Am. J. Phys. Anthropol. 134(4), 489-500.

Vidarsdottir, U.S., O’Higgins, P., Stringer, C., 2002. A geometric morphometric study of regional differences in the ontogeny of the modern human facial skeleton. J. Anat. 201(3), 211-229.

Von Cramon-Taubadel, N., 2014. Evolutionary insights into global patterns of human cranial diversity: population history, climatic and dietary effects. J. Anthropol. Sci. 92, 43-77.

Warren, K.A., Hall, S., Ackermann, R.R., 2014. Craniodental continuity and change between Iron Age peoples and their descendants. S. Af.r J. Sci. 110(7/8), 1-11.

Warren, K.A., Hall, S., Ackermann, R.R., 2015. Cranio-dental evidence for inter-population homogeneity in the archaeological record of Southern African Iron Age peoples. S. Afr. Archaeol. Bull. 70(201), 76-88.

Weber, W., Nash, D.J., Moutulsky, A.G., Henneberg, M., Crawford, M.H., Martin, S.K., Goldsmid, J.M., Spedini, G., Glidewell, S., Schanfield, M.S., 2000. Phylogenetic relationships of human populations in subSaharan Africa. Hum. Biol. 72, 753-772. 
Appendix I. Information on the Khoe-San sample under study.

${ }^{1}$ Place of deposit: VPA= Vienna Pöch Collection, Austria; NMNH= National Museum of Natural History, London $;{ }^{2}$ Sex: Male $=1$, Female $=2$.

\begin{tabular}{|c|c|c|c|c|c|c|}
\hline $\begin{array}{l}\text { Accession } \\
\text { Number }\end{array}$ & $\begin{array}{c}\text { Place } \\
\text { of } \\
\text { deposit } \\
1\end{array}$ & Country & Region & Site & Population code & $\operatorname{Sex}^{2}$ \\
\hline S1 & VPA & $?$ & $?$ & $?$ & Various KS & 1 \\
\hline S3 & VPA & ? & ? & ? & Various KS & 1 \\
\hline S10 & VPA & ? & ? & ? & Various KS & 1 \\
\hline S18 & VPA & ? & ? & ? & Various KS & 1 \\
\hline S29 & VPA & South Afr. & Western Cape & Nooitgedagt & & 1 \\
\hline S34 & VPA & South Afr. & Western Cape & Kalkbaai & & 1 \\
\hline S42 & VPA & $?$ & $?$ & $?$ & Various KS & 1 \\
\hline S58 skull & VPA & ? & ? & ? & Various KS & 1 \\
\hline S59 skull & VPA & ? & ? & ? & Various KS & 1 \\
\hline S68 & VPA & $?$ & $?$ & $?$ & Various KS & 1 \\
\hline S103 & VPA & South Afr. & Northern Cape & Kalahari & Cape KS & 1 \\
\hline S104 & VPA & South Afr. & Northern Cape & Kalahari & Cape KS & 1 \\
\hline S109 & VPA & South Afr. & $\begin{array}{c}\text { North West } \\
\text { reg. }\end{array}$ & Gamopedi & Various KS & 1 \\
\hline S110 & VPA & South Afr. & Northern Cape & Tsineng & Cape KS & 1 \\
\hline S119 & VPA & South Afr. & Northern Cape & Top Dog farm & Cape KS & 1 \\
\hline S120 & VPA & South Afr. & Northern Cape & Top Dog farm & Cape KS & 1 \\
\hline S121 & VPA & South Afr. & Northern Cape & Top Dog farm & Cape KS & 1 \\
\hline S140 & VPA & $?$ & $?$ & $?$ & Various KS & 1 \\
\hline MMM 134 & VPA & South Afr. & Northern Cape & Griqua area & Cape KS & 1 \\
\hline MMM 135 & VPA & South Afr. & Northern Cape & Griqua area & Cape KS & 1 \\
\hline $\mathrm{C} 16$ & VPA & South Afr. & Northern Cape & Marydale & Cape KS & 1 \\
\hline S2 & VPA & $?$ & $?$ & $?$ & Various KS & 2 \\
\hline S4 & VPA & $?$ & ? & ? & Various KS & 2 \\
\hline
\end{tabular}




\begin{tabular}{ccccccc}
\hline S5 & VPA & $?$ & $?$ & $?$ & Various KS & 2 \\
S7 & VPA & $?$ & $?$ & $?$ & Various KS & 2 \\
S13 & VPA & $?$ & $?$ & $?$ & Various KS & 2 \\
S19 & VPA & $?$ & $?$ & $?$ & Various KS & 2 \\
S25 & VPA & $?$ & $?$ & $?$ & Various KS & 2 \\
S38 & VPA & $?$ & $?$ & $?$ & Various KS & 2 \\
S40 & VPA & $?$ & $?$ & $?$ & Various KS & 2 \\
S46 & VPA & South Afr. & Western Cape & Valsbaai & Cape KS & 2 \\
S49 & VPA & Namibia & $?$ & $?$ & Various KS & 2 \\
S52 & VPA & $?$ & $?$ & $?$ & Various KS & 2 \\
S57 & VPA & $?$ & $?$ & $?$ & Various KS & 2 \\
S62 skull & VPA & $?$ & $?$ & $?$ & Various KS & 2 \\
S63 & VPA & $?$ & $?$ & $?$ & Various KS & 2 \\
S74 & VPA & $?$ & $?$ & $?$ & Various KS & 2 \\
S97 & VPA & South Afr. & Northern Cape & Kuruman & Cape KS & 2 \\
S98 & VPA & South Afr. & Northern Cape & Kuruman & Cape KS & 2 \\
\hline
\end{tabular}

(Following of Appendix I)

\begin{tabular}{|c|c|c|c|c|c|c|}
\hline $\begin{array}{l}\text { Accession } \\
\text { Number }\end{array}$ & $\begin{array}{c}\text { Place } \\
\text { of } \\
\text { deposit }^{1}\end{array}$ & Country & Region & Site & Population code & $\operatorname{Sex}^{2}$ \\
\hline S99 & VPA & South Afr. & $\begin{array}{c}\text { North West } \\
\text { reg. }\end{array}$ & Gamopedi & Various KS & 2 \\
\hline S101 & VPA & South Afr. & $\begin{array}{c}\text { North West } \\
\text { reg. }\end{array}$ & Gamopedi & Various KS & 2 \\
\hline S102 & VPA & South Afr. & Northern Cape & Kalahari & Cape KS & 2 \\
\hline S105 & VPA & South Afr. & Northern Cape & Kalahari & Cape KS & 2 \\
\hline S107 & VPA & South Afr. & $\begin{array}{c}\text { North West } \\
\text { reg. }\end{array}$ & Gamopedi & Various KS & 2 \\
\hline S108 & VPA & South Afr. & $\begin{array}{c}\text { North West } \\
\text { reg. }\end{array}$ & Gamopedi & Various KS & 2 \\
\hline S112 & VPA & South Afr. & Northern Cape & Tsineng & Cape KS & 2 \\
\hline
\end{tabular}




\begin{tabular}{ccccccc}
\hline S113 & VPA & South Afr. & Northern Cape & Tsineng & Cape KS & 2 \\
S115 & VPA & South Afr. & Northern Cape & Tsineng & Cape KS & 2 \\
S142 & VPA & $?$ & $?$ & $?$ & Various KS & 2 \\
C3 & VPA & $?$ & $?$ & $?$ & Various KS & 2 \\
C14 & VPA & $?$ & $?$ & $?$ & Various KS & 2 \\
C15 & VPA & $?$ & $?$ & $?$ & Various KS & 2 \\
C25 & VPA & $?$ & $?$ & $?$ & Various KS & 2 \\
PA PHR 002 & NMNH & $?$ & $?$ & $?$ & Various KS & 1 \\
PA PHR 073 & NMNH & $?$ & $?$ & $?$ & Various KS & 1 \\
PA PHR 075 & NMNH & $?$ & $?$ & $?$ & Various KS & 1 \\
PA PHR 076 & NMNH & $?$ & $?$ & $?$ & Various KS & 1 \\
PA PHR 079 & NMNH & $?$ & $?$ & $?$ & Various KS & 1 \\
PA PHR 082 & NMNH & $?$ & $?$ & $?$ & Various KS & 1 \\
PA PHR 084 & NMNH & $?$ & $?$ & $?$ & $?$ & Various KS \\
PA PHR 083 & NMNH & $?$ & $?$ & $?$ & Various KS & 2 \\
PA PHR 108 & NMNH & $?$ & $?$ & Various KS & 2 \\
\hline
\end{tabular}


Appendix II. First and second posterior probabilities (PP) of belonging to a group, obtained from the MDA for 62 individuals labelled Khoe-San and deposited in two European Museums with regional information. $1^{\text {st }} \mathrm{PP}$ in bold: $\geq 50 \%$.

${ }^{1}$ Region: WC=Western Cape (South Africa), NC=Northern Cape (South Africa), NW=North West region (South Africa), NAM=Namibia, ?=unknown region; ${ }^{2}$ Comparative groups: RR=Riet River (South Africa), ST=Sotho Tswana (South Africa), BAS=Basuku (DRC), BAH=Bahutu (Rwanda), TEI=Teita (Kenya).

\begin{tabular}{|c|c|c|c|c|c|c|c|c|c|c|c|c|c|}
\hline \multirow[b]{2}{*}{$\begin{array}{l}\text { Accession } \\
\text { Number }\end{array}$} & \multirow[b]{2}{*}{$\begin{array}{c}\text { Regio } \\
n^{1}\end{array}$} & \multicolumn{4}{|c|}{ Pooled sexes } & \multicolumn{4}{|c|}{ Only males } & \multicolumn{4}{|c|}{ Only females } \\
\hline & & $\begin{array}{c}\text { 1st PP } \\
\text { in } \%\end{array}$ & $\begin{array}{l}\text { closest } \\
\text { group }^{2}\end{array}$ & $\begin{array}{c}\text { 2nd } \\
\text { PP } \\
\text { in \% }\end{array}$ & $\begin{array}{l}\text { closest } \\
\text { group }^{2}\end{array}$ & $\begin{array}{l}\text { 1st PP } \\
\text { in } \%\end{array}$ & $\begin{array}{l}\text { closest } \\
\text { group }^{2}\end{array}$ & $\begin{array}{c}\text { 2nd } \\
\text { PP } \\
\text { in \% }\end{array}$ & $\begin{array}{l}\text { closest } \\
\text { group }^{2}\end{array}$ & $\begin{array}{l}\text { 1st PP } \\
\text { in } \%\end{array}$ & $\begin{array}{c}\text { close } \\
\text { st } \\
\text { grou } \\
\mathrm{p}^{2}\end{array}$ & $\begin{array}{c}\text { 2nd } \\
\text { PP } \\
\text { in } \%\end{array}$ & $\begin{array}{l}\text { closest } \\
\text { group }\end{array}$ \\
\hline S1 & $?$ & 50.3 & RR & 22.7 & BAH & 62.8 & $\mathrm{RR}$ & 15.7 & ST & - & - & - & - \\
\hline S3 & $?$ & 48.0 & $\mathrm{BAH}$ & 34.7 & $\mathrm{RR}$ & 49.9 & BAH & 29.9 & $\mathrm{RR}$ & - & - & - & - \\
\hline S10 & $?$ & 39.9 & $\mathrm{BAH}$ & 20.4 & ST & 40.4 & BAH & 27.6 & ST & - & - & - & - \\
\hline $\mathrm{S} 18$ & $?$ & 35.0 & $\mathrm{BAH}$ & 22.2 & $\mathrm{RR}$ & 77.9 & ST & 9.0 & $\mathrm{RR}$ & - & - & - & - \\
\hline $\mathrm{S} 29$ & WC & 68.9 & ST & 9.8 & TEI & 79.0 & $\mathrm{ST}$ & 11.6 & BAS & - & - & - & - \\
\hline S34 & WC & 28.7 & $\mathrm{BAH}$ & 22.9 & $\mathrm{ST}$ & 58.6 & $\mathrm{ST}$ & 18.0 & BAS & - & - & - & - \\
\hline $\mathrm{S} 42$ & $?$ & 35.6 & BAS & 25.0 & $\mathrm{ST}$ & 39.0 & $\mathrm{BAH}$ & 20.8 & BAS & - & - & - & - \\
\hline S58 skull & $?$ & 41.6 & BAS & 30.7 & $\mathrm{BAH}$ & 83.2 & $\mathrm{BAH}$ & 7.4 & BAS & - & - & - & - \\
\hline S59 skull & $?$ & 34.7 & BAS & 33.0 & $\mathrm{BAH}$ & 35.0 & $\mathrm{RR}$ & 26.2 & $\mathrm{BAH}$ & - & - & - & - \\
\hline S68 & $?$ & 79.2 & $\mathrm{RR}$ & 9.8 & BAS & 80.7 & $\mathrm{RR}$ & 12.3 & $\mathrm{ST}$ & - & - & - & - \\
\hline S103 & $\mathrm{NC}$ & 71.8 & $\mathrm{RR}$ & 24.3 & BAS & 83.6 & $\mathrm{RR}$ & 9.9 & BAS & - & - & - & - \\
\hline S104 & $\mathrm{NC}$ & 55.2 & BAS & 27.5 & $\mathrm{RR}$ & 39.5 & BAS & 34.3 & $\mathrm{BAH}$ & - & - & - & - \\
\hline
\end{tabular}




\begin{tabular}{|c|c|c|c|c|c|c|c|c|c|c|c|c|c|}
\hline S109 & NW & 54.6 & RR & 20.4 & $\mathrm{BAH}$ & 34.2 & RR & 29.0 & $\mathrm{BAH}$ & - & - & - & - \\
\hline S110 & $\mathrm{NC}$ & 69.7 & BAS & 18.3 & $\mathrm{RR}$ & 47.7 & BAS & 38.4 & RR & - & - & - & - \\
\hline S119 & $\mathrm{NC}$ & 90.3 & BAS & 7.8 & ST & 83.4 & $\mathrm{RR}$ & 7.0 & ST & - & - & - & - \\
\hline $\mathrm{S} 120$ & $\mathrm{NC}$ & 54.1 & $\mathrm{RR}$ & 42.4 & BAS & 67.9 & $\mathrm{RR}$ & 23.5 & BAS & - & - & - & - \\
\hline $\mathrm{S} 121$ & $\mathrm{NC}$ & 55.4 & BAS & 35.6 & $\mathrm{RR}$ & 52.1 & $\mathrm{RR}$ & 28.1 & BAS & - & - & - & - \\
\hline $\mathrm{S} 140$ & $?$ & 97.9 & $\mathrm{RR}$ & 1.7 & ST & 95.7 & $\mathrm{RR}$ & 3.3 & ST & - & - & - & - \\
\hline MMM 134 & $\mathrm{NC}$ & 34.7 & ST & 31.7 & TEI & 45.0 & BAS & 30.8 & ST & - & - & - & - \\
\hline MMM 135 & $\mathrm{NC}$ & 39.4 & BAS & 21.7 & $\mathrm{RR}$ & 37.0 & BAS & 28.8 & $\mathrm{RR}$ & - & - & - & - \\
\hline $\mathrm{C} 16$ & $\mathrm{NC}$ & 89.5 & $\mathrm{RR}$ & 6.4 & BAS & 88.3 & $\mathrm{RR}$ & 9.7 & ST & - & - & - & - \\
\hline $\mathrm{S} 2$ & $?$ & 55.1 & BAH & 13.9 & TEI & - & - & - & - & 29.4 & BA & 23.6 & BAS \\
\hline & & & & & & & & & & & $\mathrm{H}$ & & \\
\hline $\mathrm{S} 4$ & $?$ & 41.9 & $\mathrm{RR}$ & 32.2 & $\mathrm{ST}$ & - & - & - & - & 58.8 & $\mathrm{RR}$ & 24.6 & BAH \\
\hline S5 & $?$ & 52.8 & $\mathrm{RR}$ & 25.0 & $\mathrm{ST}$ & - & - & - & - & 75.1 & $\mathrm{RR}$ & 13.6 & BAH \\
\hline S7 & $?$ & 40.6 & RR & 22.4 & BAH & - & - & - & - & 44.2 & $\mathrm{RR}$ & 26.9 & BAH \\
\hline
\end{tabular}


(Following of Appendix II)

\begin{tabular}{|c|c|c|c|c|c|c|c|c|c|c|c|c|c|}
\hline \multirow[b]{2}{*}{ Accession } & \multirow[b]{2}{*}{ Regio } & \multicolumn{4}{|c|}{ Pooled sexes } & \multicolumn{4}{|c|}{ Only males } & \multicolumn{4}{|c|}{ Only females } \\
\hline & & 1st PP & closest & 2nd & closest & 1st PP & closest & 2nd & closest & 1st PP & close & 2nd & closest \\
\hline Number & $\mathrm{n}^{1}$ & in $\%$ & group $^{2}$ & $\mathrm{PP}$ & group $^{2}$ & in $\%$ & group $^{2}$ & PP & group $^{2}$ & in $\%$ & st & PP & group $^{2}$ \\
\hline & & & & in $\%$ & & & & in $\%$ & & & grou & in $\%$ & \\
\hline & & & & & & & & & & & $\mathrm{p}^{2}$ & & \\
\hline S13 & $?$ & 55.8 & RR & 26.0 & BAS & - & - & - & - & 45.9 & BAS & 29.7 & RR \\
\hline S19 & $?$ & 60.1 & BAS & 19.3 & $\mathrm{RR}$ & - & - & - & - & 74.8 & BAS & 11.9 & $\mathrm{ST}$ \\
\hline $\mathrm{S} 25$ & $?$ & 71.1 & $\mathrm{RR}$ & 17.1 & BAH & - & - & - & - & 90.0 & $\mathrm{RR}$ & 5.9 & $\mathrm{BAH}$ \\
\hline S38 & $?$ & 51.3 & $\mathrm{RR}$ & 43.6 & $\mathrm{BAH}$ & - & - & - & - & 84.6 & $\mathrm{RR}$ & 11.5 & $\mathrm{BAH}$ \\
\hline S40 & $?$ & 33.3 & $\mathrm{RR}$ & 30.4 & BAS & - & - & - & - & 37.3 & $\mathrm{RR}$ & 35.6 & BAS \\
\hline $\mathrm{S} 46$ & WC & 40.5 & RR & 37.1 & BAS & - & - & - & - & 50.3 & BAS & 31.8 & RR \\
\hline S49 & NAM & 44.7 & $\mathrm{BAH}$ & 42.2 & $\mathrm{RR}$ & - & - & - & - & 50.1 & $\mathrm{RR}$ & 38.6 & $\mathrm{BAH}$ \\
\hline S52 & $?$ & 90.3 & $\mathrm{BAH}$ & 6.3 & TEI & - & - & - & - & 96.9 & $\mathrm{BA}$ & 1.8 & TEI \\
\hline & & & & & & & & & & & $\mathrm{H}$ & & \\
\hline S57 & $?$ & 42.2 & BAH & 37.4 & ST & - & - & - & - & 61.9 & $\mathrm{BA}$ & 16.6 & ST \\
\hline & & & & & & & & & & & $\mathrm{H}$ & & \\
\hline S62 skull & $?$ & 67.1 & ST & 19.1 & $\mathrm{RR}$ & - & - & - & - & 66.7 & ST & 16.3 & $\mathrm{RR}$ \\
\hline S63 & $?$ & 93.3 & BAH & 5.0 & TEI & - & - & - & - & 97.9 & $\mathrm{BA}$ & 1.7 & TEI \\
\hline & & & & & & & & & & & $\mathrm{H}$ & & \\
\hline S74 & $?$ & 94.4 & BAH & 5.0 & $\mathrm{RR}$ & - & - & - & - & 97.3 & $\mathrm{BA}$ & 2.6 & $\mathrm{RR}$ \\
\hline & & & & & & & & & & & $\mathrm{H}$ & & \\
\hline S97 & $\mathrm{NC}$ & 60.5 & $\mathrm{RR}$ & 21.7 & ST & - & - & - & - & 91.8 & $\mathrm{RR}$ & 4.7 & BAH \\
\hline
\end{tabular}




\begin{tabular}{cccccccccccccc}
\hline S98 & NC & 48.1 & RR & 48.0 & ST & - & - & - & - & $\mathbf{7 2 . 8}$ & RR & 23.3 & ST \\
S99 & NW & $\mathbf{8 1 . 8}$ & BAS & 6.4 & TEI & - & - & - & - & $\mathbf{9 2 . 2}$ & BAS & 02.8 & TEI \\
S101 & NW & $\mathbf{5 8 . 8}$ & BAS & 29.0 & ST & - & - & - & - & $\mathbf{7 5 . 4}$ & BAS & 22.3 & ST \\
S102 & NC & $\mathbf{7 5 . 6}$ & RR & 11.1 & ST & - & - & - & - & $\mathbf{8 8 . 2}$ & RR & 4.1 & BAH \\
S105 & NC & 35.3 & RR & 33.8 & BAS & - & - & - & - & 46.3 & BAS & 27.8 & RR \\
S107 & NW & $\mathbf{5 6 . 0}$ & BAS & 19.1 & RR & - & - & - & - & $\mathbf{6 5 . 4}$ & BAS & 13.1 & RR \\
S108 & NW & $\mathbf{6 3 . 2}$ & RR & 31.3 & BAS & - & - & - & - & 49.2 & BAS & 46.4 & RR \\
S112 & NC & $\mathbf{9 2 . 7}$ & RR & 4.7 & ST & - & - & - & - & $\mathbf{8 5 . 9}$ & RR & 10.6 & ST \\
S113 & NC & 46.0 & RR & 42.6 & BAS & - & - & - & - & 49.7 & BAS & 44.2 & RR \\
S115 & NC & 43.1 & BAS & 40.6 & ST & - & - & - & - & $\mathbf{5 5 . 5}$ & BAS & 40.7 & ST \\
S142 & $?$ & 49.7 & BAH & 19.6 & RR & - & - & - & - & 45.6 & BA & 25.1 & RR \\
& & & & & & & & & & & H & & BR \\
C3 & $?$ & 42.2 & RR & 35.6 & BAS & - & - & - & - & $\mathbf{5 0 . 4}$ & BAS & 30.4 & RR \\
C14 & $?$ & $\mathbf{6 0 . 0}$ & ST & 22.9 & BAH & - & - & - & - & 49.9 & BA & 34.1 & ST \\
& & & & & & & & & & & H & & \\
\hline
\end{tabular}


(Following of Appendix II)

\begin{tabular}{|c|c|c|c|c|c|c|c|c|c|c|c|c|c|}
\hline \multirow{4}{*}{$\begin{array}{l}\text { Accession } \\
\text { Number }\end{array}$} & \multicolumn{4}{|c|}{ Pooled sexes } & \multicolumn{5}{|c|}{ Only males } & \multicolumn{4}{|c|}{ Only females } \\
\hline & Regio & 1st PP & closest & 2nd & closest & 1st PP & closest & 2nd & closest & 1st PP & close & 2 nd & closest \\
\hline & $\mathrm{n}^{1}$ & in $\%$ & group $^{2}$ & $\mathrm{PP}$ & group $^{2}$ & in $\%$ & group $^{2}$ & $\mathrm{PP}$ & group $^{2}$ & in $\%$ & st & $\mathrm{PP}$ & group $^{2}$ \\
\hline & & & & in $\%$ & & & & in $\%$ & & & grou & in $\%$ & \\
\hline & & & & & & & & & & & $p^{2}$ & & \\
\hline $\mathrm{C} 15$ & $?$ & 39.6 & $\mathrm{RR}$ & 28.2 & BAH & - & - & - & - & 64.2 & $\mathrm{RR}$ & 14.8 & BAH \\
\hline $\mathrm{C} 25$ & $?$ & 54.0 & $\mathrm{RR}$ & 22.4 & BAH & - & - & - & - & 73.2 & $\mathrm{RR}$ & 8.6 & TEI \\
\hline PA PHR 002 & $?$ & 68.6 & $\mathrm{RR}$ & 24.7 & BAS & 85.8 & RR & 6.4 & BAS & - & - & - & - \\
\hline PA PHR 073 & $?$ & 64.2 & BAS & 18.7 & BAH & 69.0 & BAS & 20.3 & ST & - & - & - & - \\
\hline PA PHR 075 & $?$ & 97.7 & BAH & 1.8 & $\mathrm{RR}$ & 84.1 & BAH & 12.1 & $\mathrm{RR}$ & - & - & - & - \\
\hline PA PHR 076 & $?$ & 53.7 & ST & 30.0 & $\mathrm{RR}$ & 52.4 & $\mathrm{RR}$ & 37.4 & ST & - & - & - & - \\
\hline PA PHR 079 & $?$ & 76.1 & BAH & 10.1 & BAS & 30.3 & BAS & 30.1 & ST & - & - & - & - \\
\hline PA PHR 082 & $?$ & 56.7 & $\mathrm{RR}$ & 36.7 & BAS & 85.6 & $\mathrm{RR}$ & 9.0 & BAS & - & - & - & - \\
\hline PA PHR 084 & $?$ & 60.2 & BAS & 20.8 & $\mathrm{RR}$ & 60.3 & $\mathrm{RR}$ & 20.6 & BAS & - & - & - & - \\
\hline PA PHR 083 & $?$ & 55.0 & BAH & 27.1 & TEI & - & - & - & - & 95.3 & $\mathrm{BA}$ & 3.4 & TEI \\
\hline & & & & & & & & & & & $\mathrm{H}$ & & \\
\hline PA PHR 108 & $?$ & 67.0 & BAH & 16.9 & $\mathrm{RR}$ & - & - & - & - & 80.8 & $\mathrm{BA}$ & 9.6 & $\mathrm{RR}$ \\
\hline & & & & & & & & & & & $\mathrm{H}$ & & \\
\hline
\end{tabular}

